\title{
Gradual Progress of ACTH Deficiency in a Child with Panhypopituitarism Associated with Pituitary Stalk Transection
}

\author{
Yukiniro HASEGAWA, Tomonobu HASEGAWA, \\ Tetsuo YOKOYAMA, Shinobu KOTOH, And \\ YUTAKA TSUCHIYA \\ Division of Pediatric Endocrinology and Metabolism, Tokyo \\ Metropolitan Kiyose Children's Hospital, Tokyo 204, Japan
}

\begin{abstract}
We present here a 13-year-old male with hypopituitarism which accompanied an insidious and gradual progress of ACTH deficiency. ACTH deficiency finally led to an overt crisis of adrenal insufficiency at the age of 12 years and 7 months. This patient is unique because the insidious and gradual progress has been proved by not only the laboratory results but also the clinical course for over 13 years. The cause of panhypopituitarism including ACTH deficiency is thought to have existed before or at the delivery because of the stalk transection seen on the magnetic resonance image (MRI). At the crisis, his laboratory results suggested that he had secondary adrenal insufficiency, whereas he showed normal adrenal function proved by the insulin tolerance test (ITT) at the age of 4 years. Abrupt crisis of secondary adrenal insufficiency developed at the age of 12 years, although he had been well until the crisis.
\end{abstract}

Key words: Hypopituitarism, Transection of pituitary stalk, Gradual progress of ACTH deficiency.

(Endocrinol Japon 39: 165-167, 1992)

GRADUAL LOSS of GH secreting ability, detected in GH stimulation tests, is well known [1,2]. The negative correlation in patients with growth hormone deficiency (GHD) between the GH peak of growth hormone releasing factor test and age [3] suggests GH secretion decreasing gradually with age in patients with GHD. We present a 13-year-old male with hypopituitarism in whom was seen insidious and gradual progress of ACTH deficiency.

Received: November 1, 1991

Accepted: January 29, 1992

Correspondence to: Dr. Yukihiro HASEGAWA, Division of Pediatric Endocrinology and Metabolism, Tokyo Metropolitan Kiyose Children's Hospital, 1-3-1 Umezono, Kiyose, Tokyo 204, Japan.

\section{Case Report}

This male patient was the $2.9 \mathrm{~kg}$ product of a 39-week uncomplicated gestation. He was born by breech delivery. Allegedly, he had asphyxia and needed to be resuscitated. At the age of 4 years, he was referred to our clinic because of short stature $(85.5 \mathrm{~cm}, \mathrm{M}-4.5 \mathrm{SD} ; 11.3 \mathrm{~kg})$, but had been otherwise healthy. Physical examination revealed a micropenis (penile length, $1.5 \mathrm{~cm}$ ) and typical face for severe growth hormone deficiency (GHD). We diagnosed him as having GHD and TSH deficiency, based upon low peak GH levels $(2.0 \mathrm{ng} / \mathrm{ml})$ during ITT $(0.1 \mathrm{U} / \mathrm{kg}$ intravenous injection) and a low basal TSH and thyroxine level (2.1 $\mu \mathrm{U} / \mathrm{ml}, 3.6 \mu \mathrm{g} / \mathrm{d} l$, respectively). At this point, ACTH and cortisol levels during ITT were normal (Table 1). He showed signs of catch-up growth after treatment with $\mathrm{GH}$ and thyroxine supplement $(123.5 \mathrm{~cm}, \mathrm{M}-2.7 \mathrm{SD}$ at the age of 11 years). 
Table 1. Serial tests for adrenal function

\begin{tabular}{llll}
\hline Age & $\begin{array}{c}\text { Cortisol levels } \\
(\mu \mathrm{g} / \mathrm{d} l) \\
\text { basal-peak }\end{array}$ & $\begin{array}{c}\text { ACTH levels } \\
(\mathrm{pg} / \mathrm{m} l) \\
\text { basal-peak }\end{array}$ & $\begin{array}{l}\text { Urinary } \\
170 \mathrm{HCS} \\
(\mathrm{mg} / \mathrm{sq} \cdot \mathrm{m} / \text { day })\end{array}$ \\
\hline $\begin{array}{l}4 \mathrm{y} 0 \mathrm{~m} \\
12 \mathrm{y} 0 \mathrm{~m}\end{array}$ & $8.2-22.3$ (ITT) & $54-89(\mathrm{ITT})^{*}$ & \\
& $4.6-7.6(\mathrm{ITT})$ & $15-18(\mathrm{ITT})$ & $\begin{array}{l}0.75 \pm 0.24 \\
(\mathrm{n}=6, \text { mean } \pm \mathrm{SD})\end{array}$ \\
$12 \mathrm{y} 8 \mathrm{~m}$ & $6.2-7.9$ (ITT) & $16-35(\mathrm{ITT})$ & \\
\hline
\end{tabular}

ITT: insulin tolerance test ( $0.1 \mathrm{U} / \mathrm{kg}$ i.v.), ACTH-T: ACTH test (40 U i.m.). *, ACTH at the age of 4 years was measured originally with an RIA kit. These ACTH values * in this Table were standarized to the IRMA values according to our relationship between RIA and IRMA (IRMA ACTH $=0.52 \times$ RIA ACTH $-6.3, \mathrm{n}=41, \mathrm{r}=0.82$ ). Normal values at our hospital (age 3-15, ACTH and cortisol were measured by IRMA and RIA kit, respectively): Cortisol peak during ITT, $28.1 \pm 17.9 \mu \mathrm{g} / \mathrm{d} l(\mathrm{n}=66$, range; $15.8 \sim 43.4 \mu \mathrm{g} / \mathrm{d} l)$; Cortisol peak during ACTH test, $56.0 \pm 20.3 \mu \mathrm{g} / \mathrm{d} l(\mathrm{n}=10$, range; $20.7 \sim 76.2 \mu \mathrm{g} / \mathrm{d} l) ;$ ACTH peak during ITT, $296 \pm 172 \mathrm{pg} / \mathrm{ml}(\mathrm{n}=64$, range; 46 663 pg/ml); Urinary 17-OHCS, $2.7 \pm 0.7 \mathrm{mg} / \mathrm{sq} . \mathrm{m} /$ day $(\mathrm{n}=10$, range; $1.7 \sim 4.0 \mathrm{mg} / \mathrm{sq} . \mathrm{m} /$ day). Normal values are shown as the mean \pm SD.

At the age of 11 years, magnetic resonance image (MRI) revealed pituitary stalk transection with high signal intensity in an ectopic posterior lobe. At the age of 12 years, he was admitted to our hospital for the evaluation of persistence of a micropenis and absence of pubertal signs. Associated secondary hypogonadism was highly suspected from the results ( $\mathrm{LH}$ peak; $<0.2 \mathrm{mIU} / \mathrm{ml}$, FSH peak; $0.2 \mathrm{mIU} / \mathrm{ml}$ ) of an LHRH test (LHRH $100 \mu \mathrm{g} / \mathrm{M}^{2}$ i.v.) and those (peak testosterone; 0.3 $\mathrm{ng} / \mathrm{m} l$ ) of an HCG test (HCG $4000 \mathrm{U} / \mathrm{M}^{2} \mathrm{i} . \mathrm{m}$. for three days). At this time, ITT and arginine tolerance tests were done to confirm GHD (peak $\mathrm{GH} ; 0.4$ and $0.4 \mathrm{ng} / \mathrm{m} l$, respectively). ITT revealed ACTH deficiency (Table 1). It was subclinical, since he had been absolutely asymptomatic until this time. Urinary 17-OHCS levels were low (Table 1). We recommended him to take glucocorticoid when he had some minor stress such as febrile, virus-like syndromes.

His life had been uneventful without glucocorticoid until he had probable adrenal insufficiency crisis (hypotension, convulsion) during an episode of common cold at the age of 12 years and 7 months. The day before the crisis he had a headache and he was febrile. On the day of the crisis, he began to vomit and could not take the previously-prescribed glucocorticoid. On arrival at our hospital, he was conscious, but complaining of light-headedness. On physical examination, his face skin and mucous membranes were pale, his extremities were cold, and blood pressure by palpatory methods was about $55 \mathrm{mmHg}$. While we were conducting the physical examination, he began to lose visual acuity and a generalized clonic seizure developed and continued for 20 seconds. A few minutes after physiological saline and glucocorticoid i.v. infusion (hydrocortisone, 100 $\mathrm{mg}$ one shot i.v., followed by continuous infusion of $100 \mathrm{mg}$ for $10 \mathrm{~h}$ ) were started, and his consciousness recovered almost completely. He took glucocorticoid (hydrocortisone) for 1 day. The plasma ACTH and serum cortisol levels (13 $\mathrm{pg} / \mathrm{m} l$ and $14.2 \mu \mathrm{g} / \mathrm{d} l$, respectively) before the treatment were compatible with ACTH deficiency. Other laboratory results (before the treatment) were the following: total protein, $6.8 \mathrm{mg} / \mathrm{d} l$; blood urea nitrogen, $30 \mathrm{mg} / \mathrm{d} l$; serum creatinine, 1.1 $\mathrm{mg} / \mathrm{d} l$; serum Na, $130 \mathrm{mEq} / l$; serum K, $3.9 \mathrm{mEq} / l$; blood glucose, $99 \mathrm{mg} / \mathrm{d} l$. The levels of BUN and Cr suggest mild dehydration with hyponatremia. We cannot explain the absence of hypoglycemia, by which a crisis of adrenal insufficiency is typically accompanied. Two weeks after he recovered, we performed an intramuscular ACTH test (ACTH$\mathrm{T}$, blood sampling before and $8 \mathrm{~h}$ after $40 \mathrm{U}$ i.m. injection of cortrosin-Z), and ITT that confirmed secondary adrenal insufficiency (Table 1). After these tests, he started daily glucocorticoid supplement (hydrocortisone, $5 \mathrm{mg}$ ). After starting the hydrocortisone therapy, he has been well until the age of 13 years and 6 months. 


\section{Discussion}

This patient was finally proved to have panhypopituitarism (GH, gonadotropins, TSH, and ACTH deficiency). The onset of panhypopituitarism including ACTH deficiency can be dated back to his perinatal period or even to intrauterine life. Although breech presentation with asphyxia and his MRI findings of pituitary stalk transection with a high signal intensity support the view that pituitary transection was due to his breech delivery $[4,5,6]$, a micropenis results from prenatal (especially the early important period for the development of external genitalia) problems. Thus, this infant could have had an intrauterine insult with prenatal stalk transection resulting in a micropenis and a breech presentation.

The patient had been asymptomatic from the time of delivery until the crisis, suggesting that his clinical course was insidious. Furthermore, laboratory data, namely, normal ACTH and cortisol reserve during ITT at the age of 4 years and the blunted reserve during ITT at the age of 12 years, suggest that ACTH deficiency in our case progress gradually.

Recently it was reported [7] that the complication of subclinical ACTH deficiency in a patient with hypopituitarism was proved several years after hypopituitarism was diagnosed at the initial evaluation, although the onset or cause of hypopituitarism was not clear in the reported case and overt adrenal insufficiency such as our patient's did not develop. Another study showed gradual progress of ACTH deficiency in adult patients with pituitary tumor after external radiotherapy, although the patients are adult and the authors did not mention their clinical course at all [1].

The reason for the gradual progress of ACTH deficiency is unknown. Gradual atrophy of ACTH producing cells in the pituitary gland may be due to gradual corticotropin releasing factor (CRF) depletion or persistently insufficient CRF secretion since panhypopituitarism in our case is considered to be hypothalamic because of the above MRI findings.

From a clinical point of view, the important aspect is knowing both the insidious and gradual progress of secondary adrenal insufficiency. In patients with possible secondary adrenal insufficiency during childhood such as hypopituitarism with multiple hormone deficiency or treated brain tumor, serial tests for adrenal function over several years are necessary even when patients are asymptomatic or even when normal adrenal function was documented before. Although patients with secondary adrenal insufficiency are not considered to be subject to developing a crisis [8], the abrupt crisis of secondary adrenal insufficiency in our patient suggests that it is very important clinically to evaluate adrenal function and to know the possibility of crisis development even if he has been well.

\section{References}

1. Littley MD, Shalet SM, Beardwell CG, Anmed SR, Applegate G, Sutton ML (1989) Hypopituitarism following external radiotherapy for pituitary tumors in adults. Quarterly J Med 70 (262): 145-160.

2. Ranke MB, Gruhler M, Rosskamp R, Broegmann G, Attanasio A, Blum WF, Bierich JR (1986) Testing with growth hormone-releasing factor and somatomedin $\mathrm{C}$ measurements for the evaluation of growth hormone deficiency. Eur J Pediatr. 145: 485-492.

3. Hanna CE, LaFranchi SH (1983) Evolving hypopituitarism in children with central nervous system lesions. Pediatr 72: 65-70.

4. Shizume K, Harada Y, Ibayashi H, Kumahara Y, Shimizu N, Hibi I, Imura H, Miura K, Saito S, Yoshida S, Tomita A, Nakagawa K, Demura H (1977) Survey studies on pituitary diseases in Japan. Endocrinol Japon 24: 139-145.
5. Kikuchi K, Fujisawa I, Momoi T, Yamanaka C, Kaji M, Nakano Y, Konishi J, Mikawa H, Sudo M (1988) Hypothalamic-pituitary function in growth hormone-deficient patients with pituitary stalk transection. J Clin Endocrinol Metab 67: 817-823.

6. Fujisawa I, Kikuchi K, Nishimura K, Togashi K, Itoh K, Noma S, Minami S, Sagoh T, Hiraoka T, Momoi T, Mikawa H, Nakano Y, Itoh H, Konishi J (1987) Transection of the pituitary stalk: Development of an ectopic posterior lobe assessed with MR imaging. Radiology 165: 487-489.

7. Crowne EC, Shalet SM (1991) Adult panhypopituitarism presenting as idiopathic growth hormone deficiency in childhood. Acta Paediatr Scand 80: 255-258.

8. Orth DN (1988) Adrenal insufficiency. In: Bardin CW (ed) Current Therapy in Endocrinology and Metabolism-3. B. C. Decker Inc, Toronto, 120-125. 